\title{
Ecological Politeness on Sedekah Bumi Ceremony in Merapi Mountainside
}

\author{
Sri Hastuti ${ }^{1,}$, St. Y. Slamet ${ }^{2}$, Sumarwati $^{3}$, Ani Rakhmawati ${ }^{4}$ \\ 1,2,3,4 Universitas Sebelas Maret, Surakarta, Indonesia \\ *Corresponding author. Email: srihastuti69@staff.uns.ac.id
}

\begin{abstract}
Sedekah bumi (earth's alms) is one of the ceremonies routinely conducted by the Javanese society. It aims to express gratitude and be used as a means to maintain the balance of nature surrounding the Merapi mountainside. This ceremony is usually conducted in the night of One Suro or known as the labuhan ceremony. The study particularly aimed to describe and analyze the ecological politeness in the ceremony of sedekah bumi in the Merapi Mountainside. The source of data were in terms of events of the ceremony of sedekah bumi and informants consisting of elders of Lencoh Village. The direct observation and in-depth interview were employed to obtain the data related to the ecological politeness in the ceremony of sedekah bumi in the Merapi Mountainside. The next step was to validate the data using the data triangulation. After conducting steps of the study and data analysis using the interactive analysis technique, there were found some facts. The ceremony of sedekah bumi in Lencoh Village is conducted in the night of One Suro or the first day in the Javanese calendar. This ceremony is carried out around the water source as a realization of respecting nature, considering the water source as the source of life. The concept of ecological politeness in the ceremony of sedekah bumi is reflected in sesajen (offering) and ubarampe (ceremonial equipments), such as jadah bakar referring to that the Lencoh community do not commit land fires so that the natural ecosystem keeps preserved. The decoration in each tumpeng (Indonesian rice cone) indicates that the safety is always maintained by not massively deforesting, so the forest sustainability is maintained. Sesajen sejodho (two offerrings) mean a couple of mountains flanking farmers in Mount. Merbabu and Merapi as the resepresentation of woman and man figures who hapily live together. The implication of the ceremony of sedekah bumi in the Merapi Mountainside is a means to remind human to always maintain the natural surrounding sustainability.
\end{abstract}

Keywords: ecological politeness, sedekah bumi in Mount. Merapi, ecology concept, Javanese traditional ceremony

\section{INTRODUCTION}

Rituals or traditions in a Javanese community become one routine necessarily conducted and preserved. It is due to that traditions contain a system of great value and philosophy. These value and philosophical systems are implied through cultural symbols in traditions. These systems are preserved so that the Javanese community always remembers and learns about them [1]. These are a representation of characters, ideologies, and souls of the community. Besides, traditions also contain hopes from ancestors to current and next generations. Hence, values require to be probably transferred and communicated to all members of the community, so messages and purposes of traditions or cultural processions are recognized and implemented well.

With respect to traditions and customs existing in local cultures, they must be different from one another. These are due to factors in terms of social backgrounds, cultures, ideologies, natural landscapes or geographical conditions, religions, and professions of communities [2]. However, these do not make a culture smaller and similar but more various and unique with special characteristic in each region. These traditions include some aspects, such as ceremonies or rituals, customs, norms or rules, and prohibitions to be necessarily obeyed by a community in a region. These aspects bind with a customary law community who still maintains their cultures and 
traditions from their ancestors [3] [23]. It is suggested that if a custom or routine ceremony does not conduct, a disaster or danger will happen to the local customary law community.

A belief in a law of cause and effect exists in communities and constructs an ideology, understanding, and suggestion having implanted in the subconscious. A belief in coexisting with nature and existence of a power from nature are closely related to communities. As a consequence, communities, consciously or unconsciously, will perform traditions to become their routines and life cycles passing through a period of time [4]. Indonesian people, in general, and Javanese communities, in particular, have traditions having carried out since the ancestral time, for instance traditions related to birth, deaths, weddings, and others. These traditions are preserved from generation to generation with reference to various motivations and purposes inseparable from the Javanese community's view of life that emphasize inner peace, harmony, and balance. This view of life is a representation of accepting all phenomena happening through placing individuals under communities and communities under nature. Besides, there are some routine ceremonies or rituals conducted as a means to respect nature that gives life and livelihood for customary law communities. An understanding about the harmony and living together with nature is planted in the customary law community's mind who still maintain ancestral culture. It becomes a means to respect nature and a representation of politeness toward nature that exists long before human.

Ceremonies or rituals conducted by Javanese communities as one of the representation of respecting surrounding environment and nature are frequently called as sedekah bumi, sedekah alam, bersih desa, merti desa, or gugur gunung. The term of sedekah is used since the ceremony is practically conducted by the communities as a representation of loving, respecting, giving some of their possession to nature [5]. Nature has a broad scope, in terms of plants, animals, and natural elements including land, air, and water surrounding the communities. The ceremony of sedekah alam or sedekah bumi generally has a purpose to give a response or to express gratitude to the God and surrounding nature. Nature has given life and livelihood to human through crops beneficial for human living.

This study used a sedekah bumi ritual conducted by the Boyolali community, especially in the Merapi mountainside, called as Sedekah Gunung Merapi. Sedekah Gunung Merapi is a tradition annually conducted in Sura month or Muharram, 1st, to celebrate the Islamic new year. This ritual is conducted as an effort of safety to God to be avoided from dangers. The Sedekah Gunung Merapi ritual is certainly related to the relationship of human and nature. The community in Merapi Mount aware that they live in the north Merapi mountainside, known as the most active mount in the Javanese island. Sedekah Gunung Merapi is particularly conducted to ask for safety from dangers resulted from Mount Merapi. The sedekah bumi ritual is conducted not only to ask for safety from disasters but also to conserve surrounding nature considering some rituals are conducted in the water source. Water sources are considered as a source of live for human, plants, animals, and other ecosystems [6]. Consequently, the Selo community has a special attention on the water source since it is suggested as both of source of life and source of livelihood.

The study on the sedekah bumi ritual conducted by the Selo community was interesting to be carried out with reference to environment and culture. It employed the ecology to study the concepts of ecological politeness and ecological wisdom in the sedekah bumi ritual in the Selo community. Etymologically, the ecology is derived from "oikos" and "logos". "Oikos" refers to a house of residence to live the life, and "logos" means science [7]. The ecology, from the view of biology, is an interdependence relationship between organisms and environment, particularly relationship between human and environment [8]. The ecological study analyses relationship and interdependence of human with nature. The ecology itself deals with a nature area consisting of organism and elements interrelated to exchange a material. Besides, Rahman, Wirawati, \& Sidiq [9] claimed that the main concept in the ecology is an emergence of a system constructed as an effect of a reciprocal relationship between human being and environment or known as an ecosystem. Elements included in the environment are water, fire, air, and earth. Besides, the environment contains human interacting with other humans, animals, plants, and other human beings. By this interaction, human lives his/her life.

Studies on the ecology have been accounted for by some researchers. Rachmawati, Warto, \& Pitana [10] investigated about selling sacredness was representation of Sedekah Gunung Ritual in Lencoh Village, Boyolali in New Media. They revealed the 
fact that a representation of sedekah gunung ritual is recorded in some articles, news, and videos in a space of new media. They suggested that these records functioned as an alternative tourism promotion in Selo, particularly Lencoh village, and media to invite tourists and increase the income from tourism sector. It implies that a construction of knowledge is disseminated as a magnet in terms of alternative tourism to attract local and foreign tourists. Besides, Asilsoy and Oktay [11] explored the environmental behaviour as the major determinant of ecological citizenship. They discussed about the ecological citizenship conceptualized as the fifth dimension, following the known dimensions of sustainable urbanism mainly concerned with the physical features of environmental management. Furthermore, environmental behaviour is explored through a literature review.

Another ecological and cultural issue was conducted by Brackhane, et al [12] on crocodile management in Timor-Leste by drawing upon traditional ecological knowledge and cultural beliefs. It explained about the conservation management of crocodile ecosystem using the local community's traditional method. It revealed that this species was a risk (respect, fear) and its population was expanding, and had culturally determined beliefs (ceremonies, rituals) that included differentiating between local "ancestor" crocodiles and invasive "troublemakers." Moreover, a study conducted by McNamara and Purzycki [13] on minds of gods and human cognitive constraints: socio-ecological context shapes belief, discussed about the concept of god and human thought in a social life based on the ecological principles and environment conservation.

Based on the previous studies, the concept of ecology is inseparable from the culture of local community. Hence, this study focuses on investigation ecological aspects in the sedekah bumi ritual in Selo, Boyolali. The interesting part of this ritual is the ecological politeness reflected in respecting the existence the surrounding nature. This ecological politeness is represented in the routine sedekah bumi ritual as a representation of gratitude to crops. In addition, the local wisdom and ecological messages are also reflected in sesaji (offerings) and ubarampe (equipment) while the ritual in which all of them have philosophies in relation to the ecological politeness.

\section{METHODS}

This study specifically aimed to describe and analyse the ecological politeness in the sedekah bumi ritual in the Merapi mountainside. The setting was Selo district, Boyolali regency. The approach deployed ethnography in collaboration with ecology. The ethnography is frequently used to collect the empirical data about communities and cultures. Data collection techniques usually use participant observation, interview, questionnaires, and so forth [14]. This science aims to describe condition of communities investigated. The source of data was the event of sedekah bumi ritual and informants in terms of Lencoh village elders. Direct observation and indepth interview were employed to collect the data related to the ecological politeness in the sedekah bumi ritual in the Merapi mountainside. To validate the data, the study utilized triangulation data techniques, in terms of theory and source of data. The valid data were then analysed using interactive data analysis with the environmental ecology and local culture wisdom approaches.

\section{RESULTS AND DISCUSSION}

Communities in Selo district generally live in the Mount Merbabu area. They are farmers who need natural resources to support their activities, such as the availability of fertile land and water. As a consequence, they have to conserve surrounding natural resources. Sedekah bumi ritual is one of the ways to maintain natural resources around the Merapi mountainside. As suggested by the Selo village elder, the community has the ancestral belief that they are obliged to live together with and maintain nature. Nature gives many beneficial aspects for human, such as water yield, crops, and lands that give the life to the community. As an expression of gratitude to nature, the community conduct a sedekah bumi ritual. Sedekah means to get safety and prosperity. Selo farmers represent the meaning of sedekah in some activities such as distributing water evenly, conducting bersih desa ritual, serving food in sedekah gunung ritual, and sadranan in each village. Besides, the sedekah bumi ritual is also a means to preserve the ancestral culture exiting for generations. The Selo community believes that each ceremony or tradition has a beneficial meaning and purpose for human life. 


\subsection{Sedekah bumi Ritual in Merapi Mountainside}

Cultures inherited from the ancestor in terms of tangible and intangible cultures are still able to be recognized in communities' daily lives. Communities attempt to maintain the sustainability of natural ecosystem to be able to live in harmony, balance, and comfort psychologically and socially [15]. The concept of maintaining the harmony and balance with nature are mostly found in the community's belief system all over Indonesia. It has different name and term in each region. In Central Java and Yogyakarta, it is called as Sedekah bumi or Larung Sesaji. Sedekah bumi or Larung Sesaji is conducted to respect mount and sea ecosystems. A mountain frequently used for Sedekah bumi or Larung Sesaji rituals is Merapi Mount, located in the border of Yogyakarta and Central Java provinces.

Bersih desa is a ritual in a region aiming to send prayer and sesaji (offerings) to water sources, sacred places, or historical places in a village or region. It is usually conducted before some ceremonies such as weddings, sunatan (circumcision), or building a house. This ritual aims to get smooth and blessed ceremonies According to Koentjaraningrat [16] bersih desa ritual contains some elements, including; (1) offering; (2) praying; (3) sacrificing; (4) eating together foods purified by prayer; (5) doing sacred dance; (6) singing holy song; (7) parading; (8) performing sacred drama; (9) fasting; (10) doing intoxication/fading mind with anaesthetic food to achieve trance/drunk; (11) isolating oneself; and (12) meditating. All of these elements unnecessarily exist in one time in every bersih desa ritual since each region has different tradition as inherited from generation to generation. The bersih desa ritual shows a slight different procedure in each village in Selo district. These differences cannot be argued or debated because each village has own special characteristics and beliefs. These eventually add cultural diversity in Selo district and become local wisdom that requires preservation. In Jeruk village, the bersih desa ritual is conducted by bringing 1 tumpeng an (cone-shaped rice) around the main reservoir of water source by a village representment. The next procession is praying, leading by a village elder until the ritual is over. In Senden village, this ritual is conducted with a scheduled wayeach dukuh alternately makes 2 tumpeng an and slaughters a sheep around a water source location. The sheep head is buried in that location. The sheep body is brought to dukuh, and its lamb is taken, then cooked and eaten together as a realization of gratitude in each Suro, 16th. The ritual between Jeruk and Senden villages are quite different in terms of time, processions, and procedures.

Tarubatang Atas Village has the bersih desa ritual conducted every Ba'da Maulud Month, on Tuesday Kliwon (Kliwon: A Javanese day) once a year. This ritual is by working together on cleaning the village around the water source location. The Tarubatang community makes 2 tumpeng an, slaughters and cooks two chickens, then brings them to the water source. Then, they pray for the food and then eat them together. In Tarubatang Bawah Village, this ritual is carried out every Safar Month in which each dukuh makes 2 tumpeng an in turn. The community slaughters a sheep around the water source location, and then its head is buried, and its body (lamb) is brought back to dukuh to be cooked and eaten together as a realization of gratitude.

Jrakah Village has the bersih desa ritual carried out every Friday Pon (Pon: A Javanese day) or Thursday's night Pahing (Pahing: A Javanese day). The ritual procession is carried out in two ways. First, each family head (KK) brings 1 tumpeng a containing vegetables and Indonesian fries which is collected at the head of Neighbourhood Association (RT)'s house. The next stage is that the community prays for the water source and continues eating together. Second, if there is a family holding a wedding celebration, the family is required to serve sesajen (offerings) to the water source. Giving of sesajen, as suggested by Zaki, et al [17] is a symbolic act of giving sesaji (sajen) for the Mbaureksa, Mbahe or Dhanyang, in banyan trees, large old trees, sendhang-sendhang, water sources (belik), graves of old figures, and other sacred places (wingit).

\subsection{Sedekah bumi Ritual in 1 Sura Night in Lencoh Village}

The sedekah bumi ritual is one of the local wisdoms routinely carried out by communities in the Merapi mountainside. This ceremony is held in Lencoh Village, Selo District every 1 Suro night. This event is a procession of offering a buffalo head and sesaji to the crater of Mount Merapi as a gratitude representation of the Selo community and its surroundings to the Almighty God. The ceremony is enlivened with dances and attractions from the local community, and then ends with a kirab of buffalo head and a heap or corn rice as sesaji placed at Bubrah Market. The ritual starts from 22:00 to 24:00. 


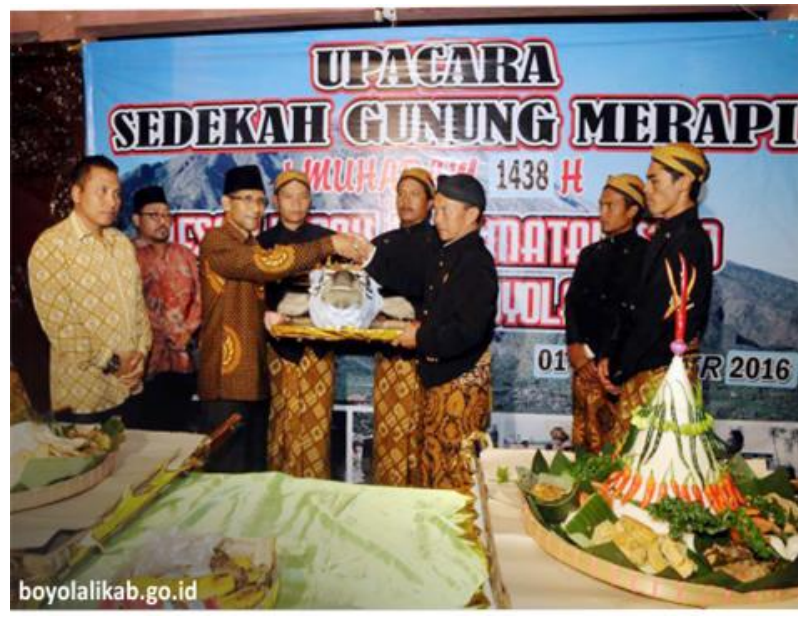

Figure 1. Opening of Sedekah bumi Ritual in Mount Merapi. Source: http://www.boyolali.go.id

There are three main events during the ceremonial procession, namely kirab sirah maeso or buffalo head, kirab saji Gunung Merapi (mount Merapi offering), and kirab of hundreads torches. The kirab of hundreds of torches becomes more attractive because it has just started and promoted in 2010. This tradition began with the tolak bala ritual (a ritual for rejecting dangers) conducted by Pakubuwono X from Kraton Surakarta by sacrificing a buffalo to Mount Merapi. The community gradually considers that the New Year's Eve in the Javanese calendar or more frequently called the 1 Suro night or 1 Muharram night in the Islamic calendar is an important night and considered sacred for many communities who live under the influence of Javanese culture. In this night, many areas in Solo Raya (Raya: surroundings) including the community who lives in the Merapi mountainside hold various types of rituals or traditional ceremonies. The followings show some documentation of the sedekah bumi ritual held by the community in the Merapi mountainside.

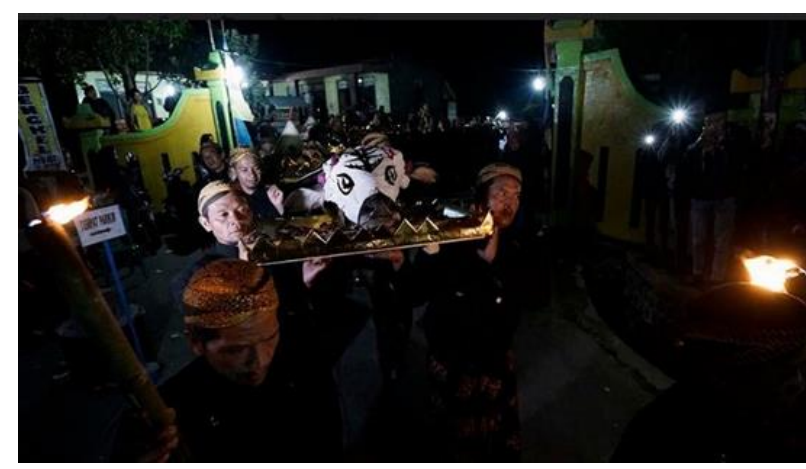

Figure 2. Procession of Buffalo Head Kirab as Offering in Sedekah bumi Ritual. Source: https://jateng.tribunnews.com
The Selo community, particularly the Lencoh Village community, are very familiar with the tradition on the 1 Suro night. In this area, located in the north mountainside that last erupted in 2010, the community knows and still carries out a tradition known as sedekah gunung or sedekah bumi. The ceremony, which is meant to beg the safety of the community living around Mount Merapi, has been held since the ancestral time. The interesting thing about this ritual is that the offering consists of a buffalo head is thrown into the crater of Mount Merapi. The community believes that Mount Merapi is guarded by Kyai Petruk. Apart from the offering the Lencoh community usually represents the ritual in terms of a festival. In the festival or procession, there are also entertainments such as dances and art performances shown by art galleries or local celebrities.

The ritual is centred in Lencoh Village. In this yearly ritual, the local community throws a buffalo head and sesaji to the crater of Mount Merapi. Sesaji are offered to the rulers of Merapi aiming to avoid the eruption. According to the community, the sedekah gunung ritual has been carried out from generation to generation since the ancestral time. The community is unlikely to leave the ritual, because it has been implanted in the local community or united with the local customs. A community member who will has a celebration usually offers foods for sesaji with elements taken from the surrounding mountain. S/he hopes to get safety and abundant agricultural products, and live prosperously because of the land fertility of Mount Merapi.

The Sedekah bumi Ritual for Mount Merapi contains several local wisdom values, including mutual cooperation, togetherness, religion, love of nature, and sharing which representation of the Javanese community's character [18]. Mutual cooperation is reflected in terms of how the Lencoh community prepares for the sedekah bumi ritual in the Merapi mountainside. The community works together while preparing sesaji and carrying out the procession so that it runs smoothly. Religion is represented in the Lencoh community's belief in always expressing their gratitude to the Almighty God who has given them blessings in terms of crops for the community. This expression of gratitude is then manifested in sedekah bumi ceremony. The procession of the sedekah bumi ritual must begin and end with a prayer by the traditional elder. 


\subsection{Sesajen in Sedekah bumi Ritual}

For the Javanese community, sesajen or sesaji has become a means necessarily presented in every traditional ceremony procession. Sesajen is derived from "sesaji" or something served. This sesajen is intended as a dish served during the traditional ceremony process. Many misconceptions exist in interpreting of sesajen or sesaji in terms of things meant for devils, supernatural creatures, or spirit watchmen [19]. In fact, sesaji or a set of sesajen is a symbol with a philosophical value and message to be conveyed to the community. In general, sesaji is in terms of various foods with containing various meanings. The sedekah bumi ritual also uses several sesaji as a complementary means in the ritual process. Sedekah gunung is originally from the story of alas Mbah Petruk who gave kebonan (fields) to a local community. That area previously has no fields, but only buffalo. Therefore, the sedekah gunung ritual is carried out in by serving a buffalo head offering as gratitude for getting the field from Mbah Petruk. Sesajen includes a buffalo head, nine tumpeng (coneshape rices), palawija (agricultural crops except rice), gudang garam klobot cigarette, ojolali cigarette, jadah bakar (roasted corn), panggang buta in which those ubarampe has to be in pairs. In the sedekah gunung ceremony, sesajen has many messages and philosophical meaning. They are the followings.

a. Tumpeng (cone-shape rice) comes from the expression of kudu tuhu lan mempeng or you have to try and have a strong intention. It deals with a message that the community has a strong harmony, lives well with the same rhythm, so has no disputes and divergence. In other words, the community is expected to be able to work together and respect one another. The youngers must also respect the older while the older must be able to guide and respect the youngers. In addition, the community is obliged to have abilities to respect and value the environment providing life and livelihoods.

b. Jadah bakar (roasted corn) means that the community does not burn the mountain so that natural conditions remain conserved. Most of the natural conditions in Selo District consist of the slopes of Mount Merapi and Mount Merbabu. These natural conditions must be maintained by the community, because the areas of Mount Merapi and Merbabu are determined as the National Park area containing many flora and fauna ecosystems. Mountains are also water sources to store water reserves that are useful for the community's lives. The purpose of offering roasted corn is to prevent acts of destroying and burning forests. If the forest gets destroyed, the natural ecosystem will be damaged and influence the lives of the surrounding community.

c. Decorations on tumpeng refer to that the security in the mountain area is able to be maintained. In addition, decorations such as vegetables and some side dishes in terms of chicken eggs also symbolize the life of the flora and fauna ecosystems around the mountain. These ecosystems must be conserved.

d. Two other sesajen are prepared in pairs, to represent the sexes of women and men. This is du to that the community makes an analogy to Mount Merapi as a man and Mount Merbabu as a woman. The number of different tumpeng deals with the number of guardians in Java island, as many as nine. There are several meanings in the sedekah gunung, such as inherited traditional ceremonies. These ceremonies must be held by the community or there is a burden on the community. Another meaning is that the sedekah gunung is a means of asking for safety and welfare for communities living around Mount Merapi and Merbabu.

e. 9 trays of palawija symbolize the presence of 7 prophets told in traditions and 2 wali as scholars who spread Islam in Java.

f. Other foods served in the sadranan event, are apem, kolak, and sticky rice cakes as the main elements of sesaji and the basis for prayer rituals. The dough for these three types of food is put into takir (foods covered by banana leaves), and sticks are stabbed on both sides. The cakes are given to older relatives, close neighbours, and also as a complement to kenduri. This tradition shows that every community member has a sense of solidarity and expresses their social piety to others. The menu provided is generally in terms of savory rice and side dishes, usually chicken. Sticky rice has a meaning of piety or commonly called as Javanese ketho'an. Meanwhile, kolak relates to truth (kolado), and apem represents a symbol of apology. This sesaji is intended to wish the spirits of ancestors having a peaceful place by His side.

\subsection{Ecological Politeness in Sedekah bumi Ritual}

The tradition of celebrating the Javanese New Year is usually held at New Year's Eve in the Javanese calendar. This tradition is commonly called 1 Suro Night or 1 Muharram Night, with another name of the sedekah gunung ritual. This activity is one of the spiritual symbols of the Javanese community. According to Adrianto [20], traditional ceremonies are formal behaviours performed for events that are shown in daily technical activities, but have a connection with powers beyond human ability (supernatural). In practice, at 1 Suro night, the community performs 
"laku prihatin" not to sleep all night. The activities include tirakatan, watching a wayang show, and other performing arts. The day before 1 Suro, the community carries out the sedekah gunung ritual. The processes are as follows: the community brings 1 large tumpeng (tumpeng agung), 1 tumpeng of corn rice, 7 trays of palawija, and the heirlooms (keris, spears, swords, samurai) to padepokan (residence) Turonggo Seto. Then, the heirlooms are washed with flower water, and then the community goes to Petilasan Kebo Kanigoro. After that, the community does the unification of holy water at Petilasan Kebo Kanigoro. The holy water is taken from the slope of Mount Merbabu, and Perwitasari water is taken from the slope of Mount Merapi. The water is then being placed in a water container for being used by the community giving sesaji [21].

There are 4 (four) meanings containing in the sedekah gunung ritual. First, the ritual is to continue the existence of the community's tradition inherited from generation to generation. Second, it provides a sense of peace since all community members participate in the ritual. Third, it is a means for the community to ask for safety and welfare, especially those who live in the Merapi mountainside, within the radius of the eruption of mountain. Fourth, uniting holy water from two mountains is a sign of harmony in the community's life and to be protected from harms.

Ecological politeness in the sedekah bumi ritual is reflected in the community's beliefs and sesajen used in the ritual. The community in Selo District has a local wisdom related to the surrounding environment. The reflection of local wisdom in terms of sesaji terms of sedekah gunung merapi ritual is a wisdom having been passed down from generation to generation in the Lencoh community as the owner of the tradition. Since the ancestral time, a concept of coexistence with nature has been emphasized. One of the ecological politeness concepts is to respect the existence of natural environment. In this context, respect is not manifested as a slogan and logo displayed in several public places, but rather reflected in real actions. The community of Selo District are obliged to always protect the environment and their surroundings. The majority of Selo community also work as farmers, a profession passed down from generation to generation. This is a clear evidence that the Selo community still maintain their ancestral culture, by keeping the natural surroundings well maintained and wisely explored without any exploitation and destructive actions. This shows that the ecological politeness of the Selo community is not only reflected in slogans, but also implemented and integrated in their daily life.

Furthermore, the ecological politeness is also reflected in cultural symbols in the sedekah bumi ritual, namely in ubarampe sesajen. Sesajen in terms of tumpeng sajodho (a pair of cone-shape rices), jadah bakar (roasted corn), klobot cigarettes, apem, and so forth represents a message from the ancestors to always protect the environment. Campaigns on preventing forest fire, destruction of ecosystems, and exploitation of nature are shown in several philosophies of sesajen in the sedekah bumi ritual. In addition, the sedekah bumi ritual is also carried out around the water source in local villages. The water source refers to the source of life, so the Selo community always protects and conserves water sources as long as they provide life and livelihood to the community. The concept of protecting the environment is also proposed by Hardisty [22] that the physical environment plays a determinant role in constructing personalities, morals, cultures, politics and religions. Thus, the perspective principles of 'Environmental Determination' are: 1) Nature and environment have a will over humans, and human life is controlled by them; 2) Humans are unable to suffer as a result of natural power existing beyond their ability; and 3) Determination of environment conditions humans to develop rites with a chain of relationships between natural movements and power of supernatural myths. Henceforth, the Selo community always carries out the sedekah bumi ritual as a manifestation of preserving the environment

\section{CONCLUSION}

Sedekah bumi or sedekah gunung is traditional ceremony routinely carried out by the Selo community. It is a means of maintaining ancestral customs and respecting natural surroundings. The community has an ancestral belief, namely that they must always live side by side with and protect nature. There are numerous benefits given by nature, such as water yields, crops, and lands that give the life to the community. As an expression of gratitude to nature, the community performs the sedekah bumi ritual. In the sedekah bumi ritual, a concept of ecological politeness is demonstrated, in terms of respecting the existence of surrounding environment. The concept of ecological politeness has been embedded in the ideology and subconscious mind of the Selo community, as portrayed in the sedekah bumi ritual. There are still many people who work as farmers and live side by side with nature. In addition, the concept 
of ecological politeness in the sedekah bumi ritual is represented in sesajen and ubarampe at the sedekah bumi ritual. One of which is Jadah bakar (roasted corn), referring to that the community does not burn lands to maintain the living ecosystem. The decorations in each tumpeng show that the security is always maintained by not deforesting to maintain forests. Sesajen sajodho (a pair of offerings) reflects that a pair of mountains, in terms of Mount Merbabu and Merapi, contributing to the livelihoods of farmers (community) is a representation of women and men. This ritual is carried out around water source as a realization of respecting nature, considering the water source as a source of life. The implication of the sedekah bumi ritual in the Merapi mountainside is a means of reminding humans to always preserve the natural surroundings.

\section{AUTHORS' CONTRIBUTIONS}

All authors contribute to the content of the paper from the beginning to the end of writing the paper.

\section{ACKNOWLEDGMENTS}

Acknowledgements and appreciation to University Centre of Excellence Javanologi for Javanese Traditions Universitas Sebelas Maret.

\section{REFERENCES}

[1] B.W. Setyawan and K. Saddhono, "Eret traditional ceremony as representation of spirit of mutual cooperation among coastal communities," Adv. Sci. Lett., vol. 23, no. 10, 2017, doi: 10.1166/asl.2017.10363.

[2] M.R. McFarland and H.B. Wehbe-Alamah, "Leininger's Theory of Culture Care Diversity and Universality: An Overview with aHistorical Retrospective and a View Toward the Future," $J$. Transcult. Nurs., vol. 30, no. 6, pp. 540-557, 2019.

[3] W. Sundari, "Preserving Javanese Culture by Junior Highschool Students in Northern Semarang District as Javanese Language Environment to Promote Local Tourism Industry," in E3S Web of Conferences, 2019, vol. 125, p. 9019.

[4] S.T. Widodo, "The Influence of Javanese Culture on the Education Curriculum in Indonesia," $J$. Educ. Pract., vol. 4, no. 19, pp. 139-143, 2013.

[5] B.W. Setyawan, "Environment Preserving Character on Wayang Story Dewa Ruci: An Ecological Literature Study," J. Kata Penelit. tentang Ilmu Bhs. dan Sastra, vol. 4, no. 1, pp. 122-132, 2020.

[6] J. Guarino, "Protecting Traditional Water Resources: Legal Options for Preserving TribalNon-Consumptive Water Use," Pub. L. Resour. L. Rev., vol. 37, p. 89, 2016.

[7] D. Sulaksono, Wayang Kulit Purwa berbasis Ekologi. Surakarta: CV Djiwa Amarta, 2017.

[8] A.A. Puspita, A. Sachari, and A.B. Sriwarno, "Knowledge from Javanese Cultural Heritage: How They Manage and Sustain Teak Wood," Cultura, vol. 15, no. 1, pp. 23-48, 2018.

[9] H. Rahman, D. Wirawati, and J.N.A. Sidiq, "Pembentukan Karakter Melalui Pembelajaran Sastra Berbasis Ekologis dalam Kumpulan Cerita Rakyat Nusantara," Pena Literasi, vol. 2, no. 2, pp. 87-92, 2020.

[10] J.I. Rachmawati, W. Warto, and T.S. Pitana, "Selling Sacredness: Representation of Sedekah Gunung Ritual in Lencoh Village, Boyolali in New Media," MOZAIK Hum., vol. 18, no. 2, pp. 178-188, 2018.

[11] B. Asilsoy and D. Oktay, "Exploring Environmental Behaviour as the Major Determinant of Ecological Citizenship," Sustain. cities Soc., vol. 39, pp. 765-771, 2018.

[12] S. Brackhane, G. Webb, F.M.E. Xavier, J. Trindade, M. Gusmao, and P. Pechacek, "Crocodile Management in Timor-Leste: Drawing upon Traditional Ecological Knowledge and Cultural Beliefs," Hum. Dimens. Wildl., vol. 24, no. 4, pp. 314-331, 2019.

[13] R.A. McNamara and B.G. Purzycki, "Minds of Gods and Human Cognitive Constraints: SocioEcological Context Shapes Belief," Religion. Brain Behav., vol. 10, no. 3, pp. 223-238, 2020.

[14] A. Wutich and A. Brewis, "Data Collection in Cross-Cultural Ethnographic Research," Field methods, vol. 31, no. 2, pp. 181-189, 2019.

[15] I. Gusmian, "Earthquakes in Javanese Theological Interpretation: The Study of Serat Primbon Manuscripts from the Yogyakarta Sultanate Palace," Sustinere J. Environ. Sustain., vol. 3, no. 2, pp. 75-88, 2019.

[16] Koentjaraningrat, Beberapa Pokok Antropologi Ssosial. Jakarta: Dian Rakyat, 1990.

[17] M.K. Zaki, K. Noda, K. Ito, K. Komariah, S. Sumani, and M. Senge, "Adaptation to Extreme Hydrological Events by Javanese Society through Local Knowledge," Sustainability, vol. 12, no. 24, p. 10373, 2020. 
[18] B.W. Setyawan and K. Saddhono, "Ceprotan Performing Art: A Traditional Folkart Based on Urband Legend," Harmon. J. Arts Res. Educ., vol. 18, no. 1, pp. 70-76, Aug. 2018, doi: 10.15294/harmonia.v18i1.9509.

[19] K. Saddhono, K.R. Pertiwi, and D. Anggrahini, "Larung Sesaji Tradition: Symbolic Meaning and Ritual Value with Water Concept in Lake Ngebel Ponorogo, East Java," in 1st International Conference on Life, Innovation, Change and Knowledge (ICLICK 2018), 2019, pp. 380-385.

[20] A. Adrianto, "Makna Simbolik Ritual Adat Tengger," J. Patrawidya, vol. 11, no. 3, pp. 794784, 2010.

[21] Y.N. Sih, K. Saddhono, and B. Setiawan, "Religious Value in Nyadran Ceremony in Ngepringan Village, Sragen," El Harakah, vol. 20, no. 2, p. 155, 2018.

[22] I.J. Gould, J.N. Quinton, A. Weigelt, G.B. De Deyn, and R. D. Bardgett, "Plant Diversity and Root Traits Benefit Physical Properties Key toSoilFunction in Grasslands," Ecol. Lett., vol. 19, no. 9, pp. 1140-1149, 2016.

[23] Haniah, S.T. Widodo, S. Suwandi, K. Saddhono, and B. Mohamad. "Investigating the traditional proverbs and their impact on cultural identity and communication: Lessons from the Madurese community" Journal of Advanced Research in Dynamical \& Control Systems 11 (05), 2019. 